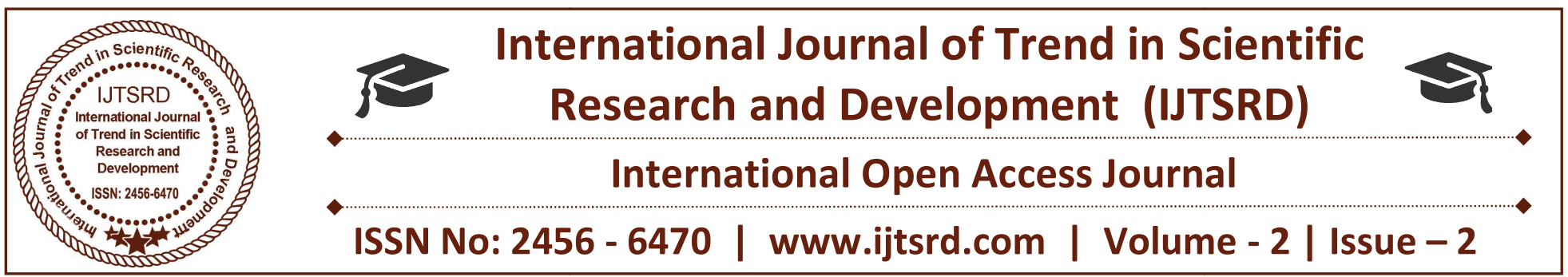

\title{
Effect of Youth Unemployment in Nigeria
}

\author{
Dr. E. M. Chukwuma \\ School of Business Studies \\ Business Administration and Management, \\ Federal Polytechnic, Oko
}

\begin{abstract}
Unemployment has become a major problem and causes that has being bedevilling the lives of Nigerian youths, causing mayhem like increased militancy, arm robbery, kidnappings violent crimes, restiveness and some many social vices. Youth unemployment has devastated the individual, families and the society as a whole both psychologically and economically. This paper examines the issues of youth unemployment and the possible ways of solving them through entrepreneurship, fighting corruption, enhancing skills acquisition and so on.
\end{abstract}

A number of recommendations were made which include that youth should be trained and engaged skillful in their field of specialists.

\section{INTRODUCTION}

Every society across the globe has its peculiar problems and challenges. Nigeria is not an exception as a developing country; she faces her own share of social, political, economic and cultural problems which has in no small measure affected the well-being of the populace. Such problems bedevilling the country include youth's unemployment, which has a serious implication for national development.

Unemployment rate in Nigeria has continued to be on the increase despite the abundant human and natural resources available in the Country. Every year, thousands of graduates are produced but there are no jobs for majority of them. In our Country, our streets are littered with youth hawkers who ordinarily would 
We are entering the era of unparallel talent scarcity, which if left unaddressed will put a broke on economic growth around the world, and will fundamentally change the way we approach workforce challenges. According to the Global Talent Risk Report (2011), youth is undeniably among the most important formidable force and resources country can have in order to boost its social economic development. Youth are energetic, courageous and poses new ideas that can make changes to the social economic development, if they are well coordinated and involved in economic activities of the country.

The problem of youth unemployment is more critical to developing countries due to the high poverty level requiring all people to work in order to ensure survival (ILO, 2011). If overlooked, youth unemployment has a potential to have significant and serious social repercussions. Youth unemployment has implications for social exclusion and division within the society (ILO, 2006). If prolonged, unemployment may have negative consequences for the later stages of working life in terms of lower wages and longer spells of unemployment. Instead, the youths have now shifted their attention to cyber crime popularly known as yahoo, yahoo or "419". This is the wrong us of technological innovation, which ordinarily should have been channeled towards technological advancement as found in U.S, united Kingdom, China and Canada, the emerging world's production and economic power. The large number of youths who are unemployed is capable of undermining democratic practice as they constitute a serious threat if engaged by the political class for clandestine activities (Adepegba, 2011).

The aim of this paper is to examine the major factors that causes unemployment in Nigeria; raise issues on the effect of unemployment on the society and discuss ways of reducing unemployment in the society.

\section{Causes of Youth Unemployment in Nigeria}

a. Rapid Population Growth: It is observed that Nigeria is the most populous country in Africa and therefore high population growth rate has resulted in the rapid growth of the labour force, which is far outstripping the supply of jobs.

b. Low Standard of Education: Because of our education system in Nigeria today, and employment of non-qualify teachers in all levels of Education, the average Nigerian graduates has been rated as unemployable because a good number of them does not possess the skills needed by the employer of labour for a formal employment. The course contents of most tertiary institutions in Nigeria lack entrepreneurial contents that would have enabled graduates to become job creators rather than job seekers.

c. Decline in Quality of Life: The decline in quality of life depend largely on family income, insecurity, intension and conflict. When there is decline in access to shelter, education, healthcare and nutritional foods are drastically reduced, this will result to reduction in life span.

Corruption: This is a cankerworm that has permeated the entire social structure of Nigeria and has robbed the country of developing a vibrant economic base. Funds meant for development projects have been misappropriated, diverted or embezzled and stocked in foreign banks, thereby killing and liquidation the economy at large.

Rural Urban Migration: The rural urban migration is another serious cause of youth unemployment. Youths move from rural to urban areas in search of greener pasture with the hope of securing lucrative employment in the industries. In addition to this, there is the concentration of social amenities in the urban centres.

Agriculture: Lampan (1974) report on the causes of unemployment stated that agriculture is the taproot of an economy. He warned that an attempt to give agriculture activities a secondary attention in the economy of any nation would sooner or later create unemployment situation. Investigation into Nigeria sources of revenue in the 1960s and 1970s showed that agricultural products were the chief source of income to the country. But with the neglect of agriculture due to oil boom, the economy late failed, and has resulted to unemployment.

Dependency on foreign made goods: This is due to neglect to the indigenous technology and inadequate patronage received by local industries from the consumers and their government as well as the rate of profit reinvestment in the foreign owned industries in the country.

\section{General Effects of Unemployment}

It is a fact that unemployment has some negative impacts on the society, people and economies. Adejumola and Tayo-olajubulu (2009) contended that 
unemployment has been identified as one of the major causes of social vices, including armed robbery, destitution, prostitution, political, thurgery, kidnapping and many others. Musari (2009) alludes to this fact by asserting that young people without any hope of getting employment has left the youths in vicious cycle of poverty that daily erodes their selfconfidence and bright future. Okafor (2005), also asserted the ruling class failed because they replaced the vision, policy and strategy, which should be the thrust of every leadership with transactions, as each successive government took turns to prey on the nation's wealth by using public power, resources, good will, utilities as instrument of abuse, and personal gain.

Among the serious problems this has brought to Nigeria are brain drain, loss of self-value and esteem, psychological trauma and loneliness, loss of drive and apathy toward work and violent behavior and social crime

\section{Solutions to Unemployment in Nigeria}

\section{Entrepreneurship Approach}

Entrepreneurship, when taking into consideration, the need to foster competiveness through innovation and creativity, recent studies have advocated to entrepreneurship as a viable tool and solution to youth unemployment. With the new contents in the tertiary institutions, young people could create enterprises as means to find and create new jobs. According to Ilo (2011), small businesses are today's main employers with $33 \%$ of jobs created over the last ten years. It shows that the large companies no longer represent the main sources of employment.

\section{Technical and Vocational Education (TVE)}

Technical and vocational education (TVE) is concerned with the acquisition of skills and knowledge for employment and sustainable livelihood. Macleon and Wilson (2009). Technical education is the training of technically oriented personnel's who are to be the initiators, facilitators and implementers of technological development of a nation. (Uwaifo, 2005). Vocational education, on the other hand is the training and relining designed to prepare individual to enter into a paid employment in any recognized occupation.

\section{Public Private Partnership}

Training to employment programs can be organized and managed by work force intermediaries like manpower Group by Government by NGO, or by employers themselves. The model is not limited to disadvantages nontraditional worker, but has been effective in reskilling experienced works who may need help in moving to related fields in response to changes in an industry.

\section{Provision of Enabling Environment for Investment and Industrialization}

Many countries of the world broke through in development because of their interest in small businesses as a catalyst for development. Nigeria has one of the highest percentages of informal sector of $65 \%$ to $/ 0 \%$, this informal sector will not only thrive and expand but will also employ over $50 \%$ of the unemployed youths in our country.

\section{Enhanced Skill Acquisition}

Hamel (1994) argued that for any person to compete effectively in an emerging economy that is knowledge -driven, he or she must possess relevant job competences including technical, business, cultural which could be obtain from functional technical and vocational education.

\section{Fighting Corruption to Finish}

Since Corruption is seem as a cankerworm and a cog in the wheel of development in our country, a fight to finish most be declared to minimize or not eliminated corruption agencies have to come out more strong, government and non governmental agencies must rise up to fight and condemn corruption in our country.

\section{Entrepreneurship as Agent of Economic Growth}

The increasing numbers of entrepreneurs as small businesses holders in many nations all over the world and the vital roles they now play in the economic selfreliance of developing countries as well as reducing the high rate of youth unemployment have attracted some serious attention to that areas. Entrepreneur has been the main agents of change in many developing and developed economic as a result of dynamism in their simple and flexible structures and driving force $f$ reduction of unemployment.

As Iguisi (2008) stressed that entrepreneur could indeed play significant role in the economic 
revitalization of Africa, as they have become the high growth poles of many African economics even as acute poverty has swamped social groups and economic conditions making the masses increasingly reactive and stressful.

The International Labour Organization (ILO) estimated that 80 percent of the people across Africa rely on small businesses and informal establishment for their livelihood. Therefore, the importance of entrepreneurship to a nation's economic development, employment generation and poverty reduction cannot be over emphasized.

Entrepreneurship is essential for rapid and sustained economic growth and development. It will creates the required man power and skills necessary for accelerated growth, reduce unemployment and poverty. It is therefore necessary and strategic for the federal government of Nigeria to assign a significant and increasing role to entrepreneurship in their effort to revamp the economy. Finally, the educational sector need to be revamped with emphasis on science and technology. This need to change the mind set of young people to embrace self employment rather than waiting for non-existing government job.

\section{Conclusion}

The rationale for employers' initiatives to promote youth employability is simple: business that can strategically source manage and create needed talents for the long term will be able to seize emerging economic opportunities. While those that fail to address this challenge will be out performed by their competitors. Individuals who are giving the access to learning opportunities and who can cultivate the right skills will thrive in the labor market and contribute to the organization that employ them.

Therefore, youth unemployment is a menace in Nigeria and constitutes $a$ real danger and a threat to Nigeria's Democracy. This is because these youth could be manipulated to undermine the stability of Nigeria's Democracy at any point in time.

\section{Recommendation}

In the light of the crucial uses discussed above, the following recommendations are made;

All tertiary institution of high learning must encourage and support entrepreneurship through their curriculum.

$>$ There must be steady supply of power to attract foreign investors an assist the local manufacturers.

$>$ Training and retraining of the youth will go a long way in building and updating their skills for future employment.

\section{References}

1) Adejumola A. S. \& Tayo-Olajubulu, T.O. (2009). Spinning off an entrepreneurship culture among Nigeria University Studies: Prospect and Challenges. Africa Journal of Business Management, 3, $81-89$.

2) Ajufio B. I. (2013). Challenges of Youth Unemployment in Nigeria. Effective Career Guidance as a Panacea.

3) Maclean R. and Wilson D. N (2009) International Handbook of Education for the changing world of work Bridging Academic and Vocational Leaning.

4) Musari A. (2009) Youth and the National Youth employment action plan. Abuja Guardian Newspaper, March, 19.

5) Okafor, E. E. (2008) Youth Unemployment and Implication for Stability of Democracy in Nigeria.

6) Uwafo V.O. (2005) Vocational Education and General Education. Conflict or Convergence, Nigeria Journal of Education Research Institute of Education. Ambrose Ali University, Ekpoma.

7) World Bank (2008): Youth Employment in Africa. Africa Development Indicators 2008/9.washington D.C. World Bank. 